This is the version of the chapter accepted for publication in The Palgrave Handbook of Development Economics: Critical Reflections on Globalization and Development published by Palgrave Macmillan https://doi.org/10.1007/978-3-030-14000-7

Accepted version downloaded from SOAS Research Online: http://eprints.soas.ac.uk/30116

\title{
Institutions and the process of industrialisation: Towards a theory of social capability development
}

\author{
Ha-Joon Chang and Antonio Andreoni
}

\begin{abstract}
Institutions were at the foundation of development economics, when it was first established as a separate branch of economics. Indeed, one important impetus behind the emergence of development economics was the recognition that developing countries have socio-economic institutions that are different from the ones that exist in the industrialised countries. The chapter provides a long term analytical perspective on the theory of institutions in economic development - from old institutionalism to new institutional economies - and critically assess todays' mainstream view on institutions and economic development. Specifically, we engage with four main analytical issues, that is, (i) the definition of institutions, (ii) the conceptualisation of the role of institutions, (iii) the theory of the relationship between institutions and economic development, and (iv) the theory of economic development. Building on this critical review, the chapter then highlights the importance of focusing on the variety of types, forms and functions that institutions have taken historically, and even more critically on their collective nature. In this respect, we build on Abramovitz's concept of social capability understood as "tenacious societal characteristics" embedded in productive organisations, as well as a variety of political, commercial, industrial and financial institutions. The chapter develops the idea of social capability by analysing and providing historical examples of six specific types of institutions and their role - forms and functions - in the industrialisation process. The institutional taxonomy includes six types of institutions: (i) institutions of production, (ii) institutions of productive capabilities development, (iii) institutions of corporate governance, (iv) institutions of industrial financing, (v) institutions of industrial change and restructuring, and (vi) institutions of macroeconomic management for industrialisation. The chapter concludes by emphasising the importance of developing productive capabilities, not just at the individual or the firm level but also at the sectoral and social level, in the process of economic development, and especially industrialisation.
\end{abstract}

\author{
Keywords: \\ Institutions \\ Economic development \\ Industrialisation \\ Social Capability \\ Institutional taxonomy
}




\section{Introduction}

The relationship between institutions and economic development is central for understanding how today's developed countries managed to transform their economies and, more critically, for designing policies for today's developing economies. There has been a long-running debate on the definition of economic development. While the majority of people have considered income level to be the ultimate measure of development, there have always been critics who emphasise that development is something more than providing higher material standards of living.

For example, according to Cimoli, Dosi and Stiglitz, development is "a process that links micro learning dynamics, economy-wide accumulation of technological capabilities and industrial development" (Cimoli et al., 2009:543). More recently, Andreoni and Chang (2017:173) conceptualised development as "a process of production transformation, led by the expansion of collective capabilities and resulting in the creation of good quality jobs and sustainable structural change".

In both these definitions, development is intrinsically associated with processes of production transformation and learning involving large segments of the society and its institutions. Institutions play a key role in the process of industrialisation. Indeed, they are at the same time both the result and one of the main drivers of economic development and manifest themselves in different ways in different contexts and time.

In economics and development economics, the research on institutions and institutional change have gone through different stages and have encountered several problems, mainly related to the difficulties that economists face in understanding the nature, variety and pervasive roles of institutions. This chapter takes up this challenge and discusses the role of institutions with specific reference to the industrialisation process. This focus is grounded on a specific structuralist view of economic development, that is, one emphasising the relationship between production transformation and institutional change.

The chapter engages with this complex subject by reviewing the history of economic analysis of institutions in economic development since the 1940s (section 2). Building on this review, in Section 3 we critically analyse the mainstream views on institutions and economic development by focusing on four main issues: i) the definition of institutions, in particular the analytical distinction pertaining their forms and functions, as well as distinctions between institutions and organisations, and between formal and informal rules; (ii) the conceptualisation of the role of institutions, beyond its constraining function; (iii) fallacies in the theory of the relationship between institutions and economic development; finally (iv) the theory of economic development.

Building on this analytical review, in Section 4 we advance an alternative theory of the role of institutions in economic development, drawing, most importantly, on Moses Abramovits's concept of 'social capability' and its emphasis on "societal characteristics" encapsulated in productive organisations as much as political, commercial, industrial and financial institutions. Section 5 develops Abramovitz's idea of social capability by identifying and characterising a number of specific institutions which have played a key role in the industrialisation process across today's developed countries. Specifically, we discuss various institutions needed for effective industrialisation - institutions of production (section 5.1), institutions of productive capabilities development (section 5.2), institutions of corporate governance (section 5.3), institutions of industrial financing (section 5.4), institutions of industrial change and restructuring (section 5.5), and institutions of macroeconomic management for industrialisation (section 5.6). The new institutional taxonomy of institutions for 
industrialisation advanced here is a first step towards a theory of social capability development.

Section 6 concludes by pointing out the need to advance our understanding of social capability development in the process of industrialisation. In particular, we emphasise the importance of recognising the variety of forms, functions and broader manifestations of institutions in different historical contexts and the ways in which they enable higher coordination in society and constitute their identity.

\section{History of Economic Analysis of Institutions in Development Economics}

Institutions were at the foundation of development economics, when it was first established as a separate branch of economics in the 1940s and the 1950s. Indeed, one important impetus behind the emergence of development economics was the recognition that developing countries have socio-economic institutions that are different from the ones that exist in the industrialised countries and therefore cannot be analysed with theories taking those institutions for granted - such as Neoclassical economics and Keynesian economics. ${ }^{1}$

For example, many early development economists - especially those who worked in the tradition of Chayanovian 'peasant economy' discourse - argued that agriculture in developing countries cannot be analysed with Neoclassical economics because agricultural producers in developing countries are not profit-maximisers, as assumed in Neoclassical economics (for a review and a critic of the theory of the 'peasant economy', see Georgescu-Roegen, 1976; Kitching, 1982). This is because agricultural production in developing countries is mostly conducted by traditional extended family units, or peasant households, which aim to maximize the average consumption of its members, and not by capitalist farms, which aim to maximize profit.

Even when the differences in institutions between the developed and the developing countries were not as explicitly highlighted as in the 'peasant economy' theory, they played important roles in early development economics. For example, in the debate concerning the famous 'falling terms of trade for primary commodities', one important argument was that the tendency exists because of the differences in the nature of the firm and the structure of the market in the developed and the developing countries (see Sparos, 1983, for further discussions). The argument was that the manufacturing firms in the developed countries are oligopolies that don't have to pass on their productivity gains to the consumers (in the developed and the developing countries), while those producing primary commodities in developing countries are mostly small firms or farms operating in competitive markets and thus have to pass on their productivity growths to the consumers (mostly in the developed countries).

While development economics was evolving, the rest of economics became less and less interested in institutions. Given the aspiration of the increasingly dominant Neoclassical school to make economics a 'science', it was thought that context-specific and often 'irrational' things like institutions have no place in economics. Neoclassical economists in the US, which established itself as the home of Neoclassical economics after WWII, ignored institutions even more wilfully, because they had to establish their

\footnotetext{
${ }^{1}$ Insights from Classical and Marxist economics, in contrast, were used much more by early development economists - Albert Hirschman, Simon Kuznets, Arthur Lewis, Michal Kalecki being the best examples - because their theories were based on the institutions of early capitalism, which were much more similar to those that exist in developing countries in the 1940s and the 1950s.
} 
dominance by beating back the Institutionalist school (a la Veblen), which had been the dominant school of economics in the country in the late $19^{\text {th }}$ and the early $20^{\text {th }}$ century. By the 1970s, when the defeat of the (American) Institutionalist school was complete, development economics remained the only field of economics that takes institutions seriously.

Unfortunately, even this state of affairs did not last long. With the neo-liberal revolution in the world of politics and in the academia, the 1980s saw the spreading and then dominance - of Neoclassical economics even into the field of development economics. When the World Bank and the IMF (International Monetary Fund) were criticised for applying 'one-size-fits-all' policies through their SAPs (Structural Adjustment Programs), which ignored local institutional contexts, the reaction from the increasingly confident Neoclassical school was that economics is a science built on universal human nature of self-seeking and rationality and therefore that policies based on scientific (Neoclassical) economic theories should work in any country, regardless of its institutional characteristics. Only those who cannot handle rigorous analytical tools of economic science, it was said, worry about 'woolly' things like institutions. As a result, during the 1980s and the 1990s, institutions largely disappeared from development economics.

However, there was an unexpected change in the fortune of institutions in development economics. Even while the dismissal of institutions by the Neoclassical economists was at its peak, the 1980s saw the rise of the so-called New Institutional Economics (NIE), which developed theoretical tools - most notably the concept of transaction costs - that allowed the analysis of institutions to be conducted in a way that is compatible with Neoclassical economics (Langlois (ed.), 1986, is a good collection of then-cutting edge works in NIE; see also Harriss et al., 1995).

According to Douglass North, one of the founding fathers of the NIE, the NIE "builds on, modifies and extends neoclassical theory" (North, 1995:17) by rethinking the instrumental rationality assumption and by recognising institutions as "a critical constraint" in the natural order of the market. North (1990:3) proposes the following definition: "Institutions are the rules of the game in a society or, more formally, are the humanly devised constraints that shape human interactions [structuring] incentives in human exchange, whether political, social or economic". In the NIE, institutions are mainly understood as necessary constraints -i.e. formal and informal systems of rules - built by human beings to reduce the high degree of uncertainty that characterizes their interactions.

This uncertainty derives from two factors: firstly the fact that, as Herbert Simon (1983) had already argued in Reason in Human Affairs, human knowledge and information are necessarily incomplete and asymmetrically distributed because of the mental computational limitation "to process, organize and utilize information"; secondly from the "non-ergodic" structure of the human domain (North, 1990:25). Transaction costs are thus considered as the very manifestation of this widespread degree of uncertainty and are used within the Neoclassical framework to explain the existence of market inefficiencies and justify the role of institutions.

The NIE was initially not welcomed by either the traditional Institutional economists, who thought it was not a 'real' institutional economics, or most Neoclassical economists, who thought it was not rigorous enough. However, with the awarding of Nobel Prize in economics to Ronald Coase (in 1991) and Douglass North (in 1993), it got clear recognition and rapidly gained in popularity, spreading beyond its original homes of the theory of the firm and the law (Coase and Oliver Williamson, 
who got the Prize in 2009) and of economic history (North), into other fields of economics, mostly notably development economics.

In the field of development economics, the big change in the fortune of institutions came between the late 1990s and the early 2000s. Institutions were suddenly talked about a lot by Neoclassical development economists and some of them even started to arguing that institutions are the most fundamental determinants of economic development. The series of 'legal origins' papers by Rafael La Porta and his associates, which extended North's work on the positive effect of the common law on economic development, was started in 1997 (La Porta et al. 1997). ${ }^{2}$ In 1999, the World Bank team led by Daniel Kaufmann started to publish the Governance Matters series of reports, in which they tried to measure the quality of institutions across the world and try to link it with economic performance (Kaufmann et al., 1999). In 2001, Daron Acemoglu and James Robinson, who have popularised the view that institutions that restrain the executive power are the most fundamental determinants of economic development, published the first of their many joint publications (Acemoglu et al., 2001). ${ }^{3}$

In 2002, under the slogan "institutions matter", the World Bank dedicated its flagship annual report World Development Report, to the issue of institutions, although the sub-title, Building Institutions for Markets, suggested a very Neoclassical approach to institutions. In 2003, the first Doing Business report of the World Bank, which soon became the barometer of business-friendliness of a country's institutions (and policies), was published. The 2017 World Development Report is the most recent attempt to capture the role of institution in economic development, with a specific focus on governance and the law. Despite some (timid) recognition of the limitations of the NIE framework, the report remains well anchored in the same framework, where institutions are reduced to mechanisms for reducing uncertainty and informational asymmetries, ultimately understood as things that enhance the functioning of the market.

The incorporation of institutions into Neoclassical development economics was not a case of an innocent scholastic awakening. Those Neoclassical economists who write about institutions rarely openly admit that Neoclassical economics was wrong to dismiss the importance of institutions. Moreover, this incorporation was suddenly made in the late 1990s, at a time when Neoclassical economists ran out of excuses for the failure of SAPs (most of which started in the late 1970s and the early 1980s), which contained all the 'good' policies based on 'scientific' Neoclassical economic theories you could blame the teething problems and time lags only for so many years, while poor implementation was a poor excuse when countries were put under very strict conditionalities. Poor institutions were a convenient 'explanation' of the failures of Neoclassical economics in action in so many developing countries. This interpretation is corroborated by the fact that the late 1990s saw a general flood of explanations of poor economic performance in developing countries (despite the introduction of SAPs) in terms of 'meta-structural' factors - like climate, geography, resource endowments, ethnic diversity, culture, and institutions (Chang, 2018). In other words, the new interest in institutions was a part of what Chang (2018) calls the ABP (or Anything But Policy) movement, intended to protect Neoclassical economics from criticisms, given the abject failure of SAPs.

Since the late 1990s, the NIE-based mainstream institutional argument has had tremendous impacts on policy-making in the developing world as well as development

\footnotetext{
${ }^{2}$ The other important work is La Porta et al. (2008).

${ }^{3}$ The other important works are Acemoglu et al. (2005) and Acemoglu \& Robinson (2012).
} 
economics in the academia. From the late 1990s, the World Bank and the IMF started to attach a lot of 'governance conditionalities' to their loans, despite the fact that they don't have the mandate to do so (Kapur \& Webber, 2000; also see chapters in Chang (ed.), 2007a). The Doing Business (henceforth DB) report - largely based on potentially highly biased 'perception based' indices - set off an international race among quite a few developing countries to climb up the league table - Rwanda even established a national Doing Business Unit in 2007 (Michaels, 2009, p. 772). ${ }^{4}$ Governance index now forms an important part of the World Bank's CPIA (Country Policy and Institutional Assessment) index, which is used for allocating resources between the poorer countries that qualify for subsidised loans from the IDA (International Development Association), an arm of the World Bank. ${ }^{5}$

\section{Problems with the Mainstream View on Institutions and Economic Development}

There are many problems with the mainstream (Neoclassical) literature on the role of institutions in economic development. Let us discuss the most important ones (see Chang, 2011, for a comprehensive critique; also see the commentaries that try to defend NIE against Chang's criticisms in the same special issue of the Journal of Institutional Economics where his article was published and Chang's reply to them).

\subsection{Definition of institutions}

The first problem with the definition of institutions in the current mainstream discourse is that it fails to clearly distinguish between the forms and the functions of institutions (see Chang, 2007b, for further discussions). For example, if we look at the World Bank's Governance Matters exercise, which compiles most major indexes of institutional quality, we find that these indexes often mix up variables that capture the differences in the forms of institutions (e.g., democracy, independent judiciary, absence of state ownership) and the functions that they perform (e.g., rule of law, respect for private property, contract enforcement, maintenance of price stability, the restraint on corruption). In response to this confusion, some have argued that the 'function' variables should be preferred over the 'form' variables (e.g., Aron, 2000), but we cannot completely ignore institutional forms. If we did that, we will be like a dietician who talks about eating a "healthy, balanced diet" without telling people how much of what they should have.

Moreover, the mainstream institutional discourse often equates institutions with property rights - or even more narrowly the 'security' of it against expropriation by the state. ${ }^{6}$ Moreover, property rights are defined in a very narrow way. Essentially only

\footnotetext{
${ }^{4}$ However, the DB index has often been criticized for being partial, not least by the former chief economist of the World Bank, Paul Romer, who, while he was in the job argued that a former director in charge of the index manipulated it, so that Chile would rank lower than otherwise, in an apparent attempt to hurt the left-leaning government of Michelle Bachelet (Source: https://www.wsj.com/articles/world-bankunfairly-influenced-its-own-competitiveness-rankings-1515797620)

${ }^{5}$ The evaluation by the Independent Evaluation Group (IEG) of the World Bank, has expressed a strong reservation about the 'governance' components of the CPIA (IEG, 2010)

6 This thought is behind the extraordinary claim that "the most important contributions to the study of institutions and development have nothing to do with ...
} 
open access, state-owned property, and private property are recognised, of which the last is uncritically assumed to be superior. ${ }^{7}$ There is little, if not no, attention paid to common property (e.g., management of the 'commons' whether they are village forests in India or sharewares on the internet), while virtually nothing is said of hybrid forms of property rights, such as cooperatives (where independent producers jointly own some properties). ${ }^{8}$

Even if we accepted that property rights are the paramount institutions, it is not clear how the institution of property rights is exactly defined. Unlike some other institutions, like the central bank or the bureaucracy, which are clearly and narrowly definable, the institution of property rights is a complex of an impossibly wide array of component institutions - just to name several most important ones, contract law, company law, tax laws, bankruptcy law, intellectual property laws, land law, urban zoning law, and customs regarding common property. If you cannot precisely define what the institution of property rights is, it is pointless to discuss its impacts.

Another critical issue arising from the widely adopted definition of institutions developed by North (1990) is the distinction between institutions and organisations. According to North (1990:4) "what must be clearly differentiated are the rules from the players", that is, the institutions setting up the incentive structures of the game from the organisations (or "teams" and "their entrepreneurs") which are the players. This conceptualisation has led to distinguishing institutions - let's say property rights - from organisations such as firms, trade unions, political parties, etc. and to treat the latter as internally homogenous players. North (1994: 361) himself states that organisations "are made up of groups of individuals bound together by some common purpose".

However, organisations are far from homogenous entities, they are themselves made up of agents with both similar and conflicting interests. As a result, in order to function and pursue a certain goal, organisations must themselves establish internal rules of interaction which make the achievement of their goals possible. In this sense, organisations like the firm can be thought as collection of rules - thus, institutions operating within a broader institutional framework - let's say a certain country or market with a certain set of rules (see March and Simon, 1958 and Penrose, 1958). This example, suggests that the distinction between institutions and organisations might be misleading and that in fact there might be other qualities distinguishing institutions of different type, for example their 'rate of change' - how stable they are or how long it takes to change them - or their 'boundaries'- that is, the extent of players or groups involved and the different interests they represent.

issues like legal systems, state-owned enterprises, financial regulation and corporate governance to corruption and political systems" (Keefer, 2011, p. 547). Also note the emphasis on institutional function (security of property rights) over institutional forms.

${ }^{7}$ Moreover, in measuring the quality of private property rights, the focus is on the protection of property holders against 'appropriation' by the government, when a lot of appropriation happens by other private sector agents (van Noort, 2018).

${ }^{8}$ Notable exceptions can be found in the work of Elinor Ostrom on governing the commons (for which she received - the only female winner - Nobel Prize in Economics), as well as contributions by Masahiko Aoki and Yujiro Hayami on the role of communities alongside markets in economics development (see Ostrom, 1990; Aoki and Hayami, 2001). 
One final ambiguity in the mainstream definition of institutions is related to the distinction between formal and informal rules. Specifically, the idea that institutions are formal constraints such as "laws and constitutions", while informal constraints are mainly associated with "norms of behaviour, conventions, selfimposed code of conduct" (North, 1994: 360). In developing countries, in particular, this distinction is highly problematic as all formal rules are intertwined with informal processes, especially with respect to the enforcement of the formal rules themselves. For example, property rights on lands are both written in systems of formal and informal rules - that is, registries and informal community entitlements - and the enforcement of these rules rely on both external and community level mechanisms for example courts and peer pressure.

To conclude, institutions (and organisations understood as institutions themselves) can take different forms and perform one or more functions, the latter being different; finally, the degree of formality of institutions is not easy to discern as it depends on the broader contextual system of rules and enforcement mechanisms.

\subsection{Conceptualising the role of institutions: constraining, enabling and constitutive}

In the mainstream institutional discourse, institutions are mainly understood as "the humanly devised constraints that shape human interactions", to use the quote from North above again. This emphasis on institutions as "constraints" stems from a mistaken perception of institutions as 'unnatural' man-made tools in contrast with the market as the natural meta-historical order.

However, as soon as we reject this 'market primacy assumption', the "enabling" and "constitutive" role of institutions become evident (Chang, 2002; Chang and Evans, 2005; Hodgson, 2006). The consideration of these two roles plays a critical role in understanding the link between institutions and economic development, as well as in designing the institutions for industrialisation through policies.

First, as stressed by Hodgson (2006: 2) "[t]he existence of rules implies constraints. However, such a constraint can open up possibilities: it may enable choices and actions that otherwise would not exist". More specifically, by "putting constraints on everyone's behaviour" institutions enable everyone "collectively to do more things" (Chang and Evans, 2005: 103), namely achieving more complex forms of coordination within and beyond the market. For example, let's consider the restriction of property rights in the form of taxation or, as another case, limitations in the use of certain assets. In the first case, by restricting the possibility of capturing the full return from an activity, taxation enables the pulling and redistribution of resources in the form of public goods and services provision. In the second case, the limitations on certain activities in the form of labour regulations or industry standards enable the achievement of higher and more complex levels of social coordination.

Second, as recognised by the old institutional economists like Veblen (1899), according to whom institutions are special types of social structures, institutions play a "constitutive" role by shaping interests but also beliefs, motivations and values (Chang \& Evans, 2005). While the direct provision of incentives, credible sanctions or constraints can modify the individual payoffs associated with different behaviours (Aoki, 2001) - these mechanisms do not change in any fundamental way individual motivations or the individual interpretations of rules. However, institutions can also reshape motivations, values and beliefs of human agents as well as the internal representation and understanding of rules, by affecting shared habits - i.e. dispositions to follow particular behaviours or rules under certain structural conditions. As Hodgson (2006: 7 italic added) argues "habit is the key mechanism in 
this transformation. Institutions are social structures that can involve reconstitutive downward causation, acting to some degree upon individual habits of thought and action". The fact that institutions "are simultaneously both structures outside individuals and ideas inside their heads" (Hodgson, 2000: 30) allows institutions to exercise their 'constitutive' role.

The recognition of this constitutive dimension should not lead to a structurally deterministic interpretation of the relationship between institutions and individuals. Instead, by combining the widely recognized mechanism of 'upward causation' - i.e. the idea that individual agents affect the development and functioning of institutions with the idea of 'downward causation', it is possible to consider the existence of a "two-way causation between individuals" motivation and social institutions" (Chang and Evans, 2005: 104).

\subsection{Theory of the Relationship between Institutions and Economic Development}

Mainstream institutional economics theorises the relationship between institutions and economic development in a very simplistic way.

First, mainstream institutional economics believes that the relationship between institutions and economic development is linear - once an institution is identified as 'good', it is believed that more of it is better. However, the impact of an institution is not linear. For example, even if some protection of intellectual property rights (IPRs) may be necessary for knowledge generation, at least in industries where copying is easy (e.g., pharmaceutical, software), too strong a protection of them is bad for the society, as it may actually discourage further innovation by making crossfertilization of ideas more difficult and by increasing the chance of technological deadlock caused by disputes between holders of inter-related patents (Chang, 2001, Chang, 2007c, ch. 6; Stiglitz, 2007, ch. 4).

Second, the relationship between an institution and economic development is implicitly assumed to be uniform across countries. So, using the IPR example again, a level of protection of IPRs that brings net benefit to a developed country may harm a developing country, as the latter will reap fewer benefits (developing countries have fewer economic agents that can take advantage of stronger protection of IPRs by inventing new knowledge) and pay higher costs (with a stronger protection of IPRs, it has to pay higher royalties to the holders of IPRs, most of whom are foreign entities) (Chang, 2001). So what may be an optimal degree of IPR protection for a developed country would be too strong for a developing country.

Third, mainstream institutional theories do not recognise the fact that the impact of the same institution on economic development changes over time even in the same society. The changing functionality of an institution over time has been a key insight of the Marxist economic theory, which argues that institutions (or 'the relations of production' in its language) that once promoted economic development (or the development in 'the forces of production' in its language) can - or rather will - turn into an obstacle to it over time. Indeed, if the strongest possible protection of private property rights were the best for economic development, as mainstream institutional economists believe, we would all still be living in in slave-based or feudal economies that we had started with.

Fourth, the mainstream institutional theories fail to recognise the inherently political nature of the evolution of the relationship between institutions and economic development. Institutions are crystalisations of power relations and therefore constantly change according to changing balance of power in a given society. Indeed, the changing functionality of an institution over time, discussed above, may be 
ultimately driven by the changes in 'economic' variables (e.g., technology, production structure, and productive capabilities), but those changes are mediated by the struggle between newly-emerging classes (economic groups, if you like) that call for new economic institutions and the old classes that resist such changes. The advocacy of the institution of banking by the newly-emerging capitalist class and the resistance to it by the landlord class in today's rich countries the $18^{\text {th }}$ and the early $19^{\text {th }}$ centuries, on the one hand, and the struggle for the institution of the welfare state by the increasingly powerful working class and the resistance to its introduction by the capitalist class in those countries in the early $20^{\text {th }}$ century, on the other hand, are the best examples.

\subsection{Poor theory of economic development}

The failure of mainstream institutional economists to properly theorise the relationship between institutions and economic development owes not only to their poor theory of institutions but also to their poor theory of economic development (see Andreoni and Chang, 2017 for a critique of the Neoclassical theory of economic development and specifically, its lack of focus on production; also see Chang, 2010). The NIE, which is at the basis of mainstream discourse on institutions and development, has a really very poor theory of how economies develop and therefore a very poor understanding of the range of functions that institutions need to perform for economic development and the forms that those institutions could take.

In the NIE, all that is needed for economic development is to protect property rights (so that investors can be assured of their ability to reap the fruits of their investments) and, secondarily, to reduce transaction costs (making it easier to 'do business' by reducing 'red tapes' and by improving potential entrepreneurs' access to finance through financial deregulation). There is no theory of how things are produced, before they can be 'transacted', and how the process of production can be improved.

In the Coasian theory of the firm (Coase, 1937), "production costs determine the technical substitution choices [while] transaction costs determine which stages of the productive process are assigned to the institution of the price system and which to the institution of the firm" (Langlois, 1998: 186). Thus, the firm emerges as a more convenient way of implementing the production process and the lowest cost option for obtaining control over the relevant factors of production. However, the institution of the firm may not simply be a way of reducing transaction costs. It may in fact be the most effective vehicle for the creation and development of productive capabilities. Penrose's (1959:149) definition of the firm as "a pool of resources the utilisation of which is organized in an administrative framework" highlights a theory of economic development centred around the process of learning-in-production, in which the firm is the main institutional vehicle for structural transformation, in contrast to the Coasian theory in which the firm is simply a way of reducing transaction costs (Andreoni, 2014).

Given the narrow conceptualization of the firm in the NIE framework, it is not surprising that there is no recognition in the mainstream institutional literature that active attempts need to be made to establish effective production units - modern firms, as opposed to traditional craft units, for example (Andreoni and Scazzieri, 2014). There may be technology and knowledge in the mainstream models, but there is scant recognition that a lot of institutions are needed in order to help firms acquire, adapt, and improve their productive knowledge (e.g., technologies, managerial techniques, organizational capabilities and worker skills).

There is particularly poor understanding that these learning activities are conducted by firms not in isolation but as parts of an industrial ecosystem (Andreoni, 
2018), which is made up of an array of institutions that promote collective productive capabilities. The importance of certain inputs with public goods nature for economic development (e.g., infrastructure, investment in basic - rather than commercial - R\&D) is recognized, but their provision is vaguely seen as the job of the 'government' and the diverse institutional forms that can - and should - provide such inputs (e.g., government ministries, public intermediaries, industry associations, public-private partnership, cooperatives) is not recognized.

\section{Institutions and social capability development}

Moses Abramovitz (1986) introduced the concept of social capability to capture exactly those "tenacious societal characteristics" that determine the responses of given societies to economic opportunities. Abramovitz includes in social capabilities not just managerial competencies (especially in the organisation and management of large-scale enterprises) and technical competences but, more crucially, also the set of political, commercial, industrial and financial institutions with which a country is endowed.

The concept of social capability was thus introduced with the specific aim of bringing in a series of specific types of institutions that remained outside mainstream explanations of economic development and traditional growth models. Abramovitz's most complete systematisation of the concept was presented in 1991 and published in volume on social capabilities in 1995. His analysis starts from an historical account of different countries' catch-up experiences and technology convergence trajectories (the latter measured in terms of the reduction in productivity gaps). Looking at a large number of countries, the historical evidence reported by Abramovitz (see Kutznets, 1966; Maddison, 1989) suggested certain general tendencies. Specifically, Abramovitz found that "in the post World War II years from 1950 to 1980, only among the small set of highly industrialized countries is there a clear tendency for levels of productivity to converge. There was no such clear tendency among the group of partially industrialized, middle income countries. And among the poorest countries, there was even a suggestion of divergent experience" (Abramovitz, 1995, 22).

Abramovitz's historical and comparative national evidence clearly contradicted the convergence/catch-up hypothesis and represented a puzzle for mainstream theories of economic development and growth. Abramovitz focused on four potential explanations, namely: (i) natural resource scarcity; (ii) technology congruence; (iii) factors supporting the rate of realisation potential; (iv) social capability.

The relevance of the first factor is considered "hard to appraise a priori" but increasingly "of much diminished importance". Abramovitz also stressed that "apparent scarcity may itself be a result of failure to develop the resources available but badly exploited" (Abramovitz, 1995: 26; see Andreoni, 2015 for an in-depth analysis of manufacturing development under resource constraints).

The second factor corresponds to what Kuznets (1968) called "relevant technology". If we remove the mainstream economic assumption that "technology that represents best practice in [the countries that have the highest productivities] can [always] be efficiently exploited by the backward economies", we can explain why economies may fail to catch up and converge in productivity levels (Abramovitz, 1995: 14-15). Technological incongruity or irrelevance may result from disparate factor proportions (typically when the technologies are capital-intensive and, thus, expensive to apply in a capital scarce/labour abundant context) or from scale problems, both with respect to market size and institutional factors. 
The third factor is defined by both internal and international policies affecting trade, capital flows, currency exchange rates and employment. The design, implementation and enforcement of domestic policies via several institutional arrangements play a key role in triggering countries' structural transformation. However, the effectiveness of these internal policies, indeed the same possibility of implementing them, will critically depends on the international policies and how they potentially affect the policy space of governments in developing countries. The international policies include several multilateral and bilateral trade agreements, but also institutions like intellectual property rights, standards and regulations (Andreoni et al. 2018).

Fourth and finally, the social capability factor is understood as composed of two classes of elements: (i) "people's basic social attitudes and political institutions" and (ii) collective "ability to exploit modern technology". The former encapsulates the socalled Kuznets triad (secularism, egalitarianism and nationalism), while the latter comprises the capacity of collectivities to deal with the "three technological feature of modern production - scale and specialisation, capital-intensity, and expanded auxiliary activity" (Abramovitz, 1995: 35). This latter deliniation of the idea of social capability is consistent with a view of development as "a process of production transformation, led by the expansion of collective capabilities and resulting in the creation of good quality jobs and sustainable structural change" (Andreoni and Chang, 2017: 173).

The concept of social capability advances a powerful idea, namely that economic development is not simply a firm-level affair (or state endeavour), but rather is made possible by the development of various types of social capability encapsulated in specific types of institutions operating at different levels of the economic system and at its interstices (intermediate institutions) to coordinate productive activities. In different historical contexts, these institutions take different forms and performs different combination of functions, and might show different levels of social capability.

In Abramovitz's original definition, social capabilities were mainly associated with productive organisations and the set of political, commercial, industrial and financial institutions driving economic growth. In the following section, we develop Abramovitz's idea of social capability by identifying and characterising a number of specific institutions which have played a key role in the industrialisation process across today's developed countries. Indeed, alongside institutions for industrialisation, there are others who have been equally important in providing public goods and favouring social cohesion throughout phases of structural transformation of the economy. Given that the consideration of these latter institutions goes beyond the scope of this chapter, for a thorough analysis of the role of the state and other institutions in economic change see Chang and Rowthorn (1995).

\section{Institutions for Industrialisation}

In the above, we argued that the NIE-based mainstream literature discusses the role of institutions in economic development at an excessively general level and at that on the basis of a very poor theory of how economies develop. This means that we need to discuss institutions at a much more disaggregated level and with more reference to concrete institutional forms. Specifically, we need to understand how specific types of institutions equip societies with those social capabilities without which the industrialisation process would not be possible.

This need for a more disaggregated and concrete approach becomes even stronger when we focus on industrialisation (and in particular the development of the manufacturing industry), rather than economic development in general. Even though 
we believe that industrialisation is the central motor force of economic development, it has characteristics that separate it from other aspects of economic development, which in turn means that its promotion requires particular institutions that serve functions that are particularly necessary for industrialisation.

Let us examine some of the key institutions that are crucial for successful industrialisation.

\subsection{Institutions of production}

As symbolised by Adam Smith's discussion of division of labour in a pin factory in the very first chapter his book, The Wealth of Nations, the rise of the factory system lay at the root of modern economic development. Drawing on Charles Babbage, Karl Marx also wrote extensively - and very incisively - about the rise of the factory system and its evolution until the mid- $19^{\text {th }}$ century. The factory system departed from both the job-shop and putting-out (a primordial buyer-driven value chain) institutional modes of production, which were dominant until the late- $18^{\text {th }}$ century. The factory was a new institution of production that brought together related producers ('artisans') under one roof, forced them to specialise, combined their physical power and skills with machines, and bound them together in an integrated process of production.

Naturally, the factory system has gone through a long and complicated process of evolution since the days of Smith and Marx (see Andreoni, 2014 for an in-depth discussion of the evolution of the different modes of production). In the late $19^{\text {th }}$ century emerged the institution of Taylorism (or scientific management system) based on de-skilling of workers and the reduction of their control over the labour process. In the early $20^{\text {th }}$ century came the institution of mass production, or Fordism, which used standardised (and thus interchangeable) parts, dedicated machinery, and moving assembly line, to produce standardised products on a large scale at a low unit cost. In the late $20^{\text {th }}$ century emerged the lean production system, or Toyotaism, which uses machines that allow quick change-overs between different models (e.g., by allowing a quick exchange of dies), workers who have multiple skills and greater control over their labour process, and components and parts delivered 'just in time' (and thus eliminating inventory costs) by long-term sub-contractors (with dedication to enhancing product quality).

Alongside these organisational innovations within the firm, the organisation of the industry increasingly relied on new institutional forms - industrial districts, industrial clusters and industrial ecosystems. While industrial districts were already discovered by Alfred Marshall, their diffusion since the 1970s represented an important move beyond the institutional dichotomy juxtaposing the market and the vertically integrated firm as the two main coordination mechanisms (Richardson, 1972; Piore and Sabel, 1984; Andreoni, 2018). Since the late 1990s, we have also seen the geographical spread and the organisational sophistication (but not the 'invention' - it was invented in the 1950s, with countries like South Korea and Taiwan as the lowest-level sub-contractors) of the global value chain (GVCs).

Developing countries that aspire to industrialise these days need to adopt and develop simultaneously all these different institutions of production from different eras. Indeed, technological changes might lead to the rediscovery of old institutional solutions in advanced economies as well. The institution of the factory is taken for granted in the industrialised countries, but the least productive producers in developing countries will struggle even just to run a factory. Many others may be able to run the Taylorist system, but would find the technological and organisational 
complexities involved the Fordist mass production system overwhelming. The more advanced ones that can manage a Fordist system may find it difficult to operate with the institution of lean production. With the growing importance of GVCs, many of the more advanced producers in developing countries will have to learn to climb up the value chain alongside developing their local production systems, while the most advanced ones will have to find a way to establish their positions as main top-tier suppliers in GVCs or even establish their own GVCs, based on a significant amount of unique knowledge in terms of technologies, managerial techniques, and worker skills.

\subsection{Institutions of productive capabilities development}

Needless to say, the evolution of the institutions of production that we discussed above - the factory system, the Taylorist system, the Fordist system, the lean production system, the industrial districts and clusters, the GVCs - are precisely manifestations of productive capabilities development. These institutions have increased our capabilities to produce by organising existing productive capabilities better (e.g., greater division of labour that allows specialisation and the exploitation of increasing returns, the introduction of the conveyor belt system that improves work flows, outsourcing to foreign companies with potentially greater efficiency).

However, producers also need to develop institutions that increase their capabilities to produce.

Some of the institutions that promote developments in productive capabilities are internal to the firm. Since the late 19th century, many corporations have set up their own research laboratories ('corporate labs') and generated own innovations as well as adapting existing technologies, as emphasized by Joseph Schumpeter and Alfred Chandler. Perhaps among the most famous examples are the Bell Laboratories. Some companies have developed rather elaborate institutions of worker training in an attempt to encourage knowledge accumulation and transfers among workers. These include dedicated training institutes, systemized on-the-job training schemes, and jobrotation and secondment systems (that broaden the capabilities of the workers).

However, many of these institutions for productive capability development are at least partly external to the firm, reflecting the fact that innovation (and knowledge generation more generally) is a collective endeavour that goes beyond the boundaries of the firm. In fact, today's industrialised countries have all established "public technology intermediate institutions" at early stages of their industrialisation (Andreoni, 2016). During the $19^{\text {th }}$ century the US established a network of agricultural extension and engineering experimental stations. During WWII, the US federal government built on and extended this technology infrastructure model to other sectors. This led to the establishment of one of the most advanced institutional infrastructure conducting basic research and development (R\&D), comprising national laboratories as well as other institutions managing technological innovations initiatives. Today's major players include the Department of Defense, the National Institutes of Health, the National Science Foundation (NSF), the National Institute for Standards and Technology (NIST), the Departments of Energy and Agriculture, and the National Aeronautics and Space Administration.

Modelled after the the US network of agricultural extension and engineering experimentation stations, in 1902 Japan established the Kohsetsushi Centres. Since then, these centres have constituted the main intermediate institutions supporting local SMEs with a variety of quasi-public good technologies for testing, trial production, and scaling-up, as well as training services. A number of sector-specific centers also 
support SMEs in the adoption of new advanced technologies and conduct joint applied research. This institutional network is complemented by cutting-edge research institutes, such as the National Institute of Advanced Industrial Science and Technology (AIST).

Many of the intermediate institutions are 'hybrid' institutions, involving both public and private sector actors. This is the case of the Fraunhofer-Gesellschaft Institutes, founded in Germany in 1949 to undertake collaborative manufacturing research and address technological challenges for the entire industrial system (big and small companies, public sector included). Over the years, the network has grown to 57 institutes (with 18,000 staff members) and come to specialize in joint precompetitive research, joint bilateral applied research with individual firms, prototyping, scaling-up of production, commercialization of new product ideas, and technology transfer schemes. Fraunhofer Institutes also conduct cutting-edge research not only at the sectoral level but also at the level of technology platforms, such as optics, photonics, micro-electromechanical systems, advanced and composite materials, advanced machining, etc..

These institutional models were adopted by the successful late industrialisers in East Asia - including South Korea (ETRI: Electronics and Technology Research Institute), Taiwan (ITRI: Industrial Technology Research Institute) and Singapore (Singapore Institute of Manufacturing Technology) - but also in Latin America and Africa, especially in the agricultural sector. Brazil's Embrapa (Empresa Brasileira de Pesquisa Agropecuária, or Brazilian Agricultural Research Corporation) is the best example (see Andreoni and Chang, 2014). They were also adopted as elements of regional industrial policies in successful regions in Europe (e.g. Emilia Romagna in Italy; see Andreoni, et al. 2017). These institutions provides critical technology, especially the provision to SMEs of public- and quasi-public-good technologies ${ }^{9}$. They have also helped companies with absorbing new technologies, adopting more effective organisational model, commercialising innovations and meeting international (product and process) standards. ${ }^{10}$

Some countries have produced high-quality skilled workers through (predominantly public) institutions of technical vocational education and training (TVET). - These are especially famous in Germany and Switzerland where the dualapprenticeship models were invented and refined over the years, but were also successfully used in countries like Japan and Korea. These institutions have played a central role in providing industrial sectors with a skilled workforce, including through re-training of existing workers.

Moreover, private sector firms themselves have set up institutions that promote productive capability development beyond their individual boundaries. In many countries, 'peak' business organisations (e.g., chamber of commerce, the employers' association) and sectoral councils have provided institutional mechanisms

\footnotetext{
${ }^{9}$ As highlighted by Gregory Tassey (2005:103), basic science is a public good, while "the fact that specific elements of an industrial technology are quasi-public goods means that their efficient development over the entire life cycle requires a mixture of public and private funding, distributed according to the magnitude and duration of various market barriers".

${ }^{10}$ With the spreading of international trade, institutions in charge of developing, certifying and enforcing technical standards have acquired a central role. Standards play an important role in technological innovation activities, especially with the increasing complexity of product and their product system features.
} 
of knowledge sharing and development in selected areas. In some countries, most notably in Italy and Germany, SMEs have formed cooperative institutions that promote their knowledge acquisition - such as joint R\&D labs or the mechanisms to share orders (and thus the productive knowledge involved) amongst member firms (Andreoni et al., 2017).

\subsection{Institutions of corporate governance}

Industrialisation in today's developing countries requires the development of large, modern corporations that can mobilise large-scale finance, handle large-scale technologies, and operate within sophisticated global supply chains. Thus, the institutions of corporate governance, which is a non-issue in under-developed economies with small farms and artisanal producers, becomes extremely important for a country that wants to industrialise.

In mainstream institutional economics, there is a lot of discussion of corporate governance, although it is focused on the fight over the division of 'surplus' between the (professional or owner-) managers, different groups of shareholders (e.g., dominant, minority), and other stakeholders (especially bond-holders or lending banks but also workers or 'local communities'). The main argument, exemplified by the 'legal origins' literature, is that a corporate governance system that accords stronger protection of investors - especially minority shareholders, who are subject to the risk of appropriation by dominant shareholders - is better for corporate investments and thus for economic development.

We have already raised issues with the view that a stronger protection of property rights is better for economic development, but that view becomes even more problematic when it comes to industrialisation (or the development of the manufacturing industries), which requires particularly long-term commitments of capital to assets that are often very specific to particular industries. So, what are the functions that institutions of corporate governance have to perform, if industrialisation is to be promoted?

The 'global standard' (read Anglo-American) corporate governance institutions, recommended by mainstream institutional economics, is based on the view that shareholders will maximise their investments when they find exit from a company easy. If exit is difficult, these shareholders lose their only power to discipline the dominant shareholders and/or the professional managers and expose themselves to the risk of exploitation by the latter groups. However, writers like Ajit Singh (1971 and 2003) and William Lazonick (2009 and 2014) have shown that the ease of entry and exit by shareholders in their corporate governance system is exactly what is making it difficult for Anglo-American companies to make long-termoriented investments needed in manufacturing industries.

Non-Anglo-American developed countries have developed institutions that create blocs of stable, long-term shareholders (or some other stakeholders, like workers) and thus managed to create a better environment for long-term investments, although these institutions are currently under pressure from short-term shareholders, especially from the US and the UK. The most prominent examples include: (a) shares with differential voting rights - an institution that is most prominently used in Sweden ${ }^{11}$ but also used by the US as well as other European countries; (b) cross-

11 This has enabled the Wallenberg family in Sweden to have controlling stakes in companies whose collective capitalisation accounts for around 50\% of Stockholm stock exchange. 
shareholding between friendly companies, most prominently used in Japan; (c) circular shareholding between companies in a family-dominated business group, which is most prominently used in South Korea; (d) the co-determination system that gives power to workers, who tend to have longer-term view than shareholders, in long-term decisions like M\&As (mergers and take-overs), most prominently used in Germany but also by some other European countries.

\subsection{Institutions of industrial financing}

In addition to the corporate governance system that can encourage long-termoriented investments, industrialisation requires external financial institutions that can provide long-term financing.

Financial system structures have been continuously transformed since the beginning of the industrial revolution. Historically, cooperative and popular banks have played a central role during the initial stages of countries industrialisation, by specialising their role in the financial system. The structural transformations of the productive sector and the increasing use of capital-intensive technologies have induced changes in the financial systems structure, at least in those countries that underwent the second industrial revolution (Gerschenkron (1962: especially chapter $5)$.

In developing countries, commercial banks typically provide short-term loans of 6 months to a year, even though they may roll them over for over a substantial period. Similarly, in developed countries, while commercial banks can provide medium to long-term financing, they tend to lend mainly short-term. However, many industrial investment projects have long gestation periods, making it very difficult to secure the necessary financing through those banks. Consequently, many countries have tried to set up financial institutions that allow companies to get access to longterm financing as well as other forms of hybrid financial services combining credit, grants and public procurement (Andreoni, 2016).

First, there is the development bank, which typically provides long-term loans of 5 years or more. The most successful ones have been KfW (Kreditanstalt für Wiederaufbau: Bank for Reconstruction) of Germany, JDB (Japan Development Bank) of Japan, KDB (Korea Development Bank) of Korea, and BNDES (Banco Nacional de Desenvolvimento Econômico e Social: National Bank for Economic and Social Development) of Brazil. Many of them have undergone institutional changes in response to the changing needs of the industrial sector. For example, since its foundation in 1947, KfW has increasingly moved away from direct lending and become a long-term refinancing bank specialized in lending to banks working with industries. KfW is still owned by the Federal government today ( 80 percent) as well as by landers (20 percent). ${ }^{12}$

Second, countries like Germany, Japan, and Korea have set up public banks that specialise in lending to manufacturing firms - especially SMEs. Among the lateindustrialisers, China is the most stricking example in this respect. State 'policy banks', as well as local governments, have played a critical role in providing targeted financial support (and special conditions) to companies in 'pillar' industries, especially the SOEs. The Export-Import (Exim) Bank of China, the Agricultural

12 The German financial infrastructure also includes the German Bank for Settlements (AG) and an articulated multi-layered system of public saving banks and credit cooperatives working with SMEs. 
Development Bank of China (ADBC), and China Development Bank (CDB) are still critical arms of industrial policy implementation in China.

Third, some countries set up long-term-oriented public investment funds as well as relying on hybrid financial solutions. For example, in the US, the Small Business Administration (SBA) runs two Funds, namely the Small Business Investment Company (SBIC) and the Small Business Innovation Research and Technology Transfer (SBIR/STTR). These Funds combine loans, R\&D grants, and pre-commercial public procurement to support small businesses, Original Equipment Manufacturers (OEMs), and specialist manufacturing contractors engaged in the development and the scaling-up of technological systems or components (sometimes for niche segments).

\subsection{Institutions of industrial change and restructuring}

Manufacturing industries require not only long-term investments but also investments in (physical and human) assets with high specificity - or limited mobility, if you will. This means that the restructuring process in manufacturing is far more difficult - both technologically and politically - than a similar process in other sectors of the economy. This also means that restructuring becomes increasingly difficult with industrial development, as higher-productivity industries typically involve more specific assets. An agrarian producer trying to change its main crop to another may have little capital equipment and few skilled workers that can be used only for the existing crop. A producer of garments trying to move into making stuffed toys may have to change some machines and train workers in the new operation for several weeks. The task involved will be far more difficult than when a producer of steel tries to move into manufacturing computers, as the blast furnace cannot be re-moulded into machines making computers and the steel workers cannot be easily re-trained as computer engineers. Therefore, the restructuring process becomes very conflictual and institutions that can manage conflicts need to be devised (for further arguments on conflict management, see Chang \& Rowthorn, 1995, and Hope \& Chang, 2018).

In the mainstream literature, these restructurings are seen as mainly happening through: (a) the M\&A mechanism of the stock market; (b) the bankruptcy law, which help wind down existing enterprises; (c) private equity funds, especially the "vulture funds', that specialise in restructuring companies; (d) the bond market both through the issuing of 'junk bonds' (which are issued by managers who have taken over and are restructuring ailing companies) and through the dealing in secondary bond markets (in the bonds of companies that is going through restructuring).

These institutions, however, tend not to be very good at long-term-oriented restructuring, as the incentives they create are all short-term-oriented. Shareholders support M\&A attempts because they give them greater dividends, higher share buybacks, and capital gains (even if the M\&A is not successful), even though the process may (and indeed is highly likely to) reduce long-term investments. Private equity funds typically have explicitly limited time horizons of 3-5 years. Junk bonds necessitates highly speculative investment projects, while secondary bond markets are by definition highly speculative, trading in bonds whose returns are highly - if not totally - uncertain.

The problem of short-termism in the Anglo-American institutions of corporate restructuring has prompted many countries to come up with alternative institutional mechanisms for corporate restructuring. First, many countries have made hostile takeovers impossible or very difficult through various measures - Japan used crossshareholding and Korea used circular shareholding to make hostile take-over 
practically impossible, while Germany used the co-determination system to achieve the same purpose. Second, the 'main bank' system of Germany and Japan, in which the leading lending bank of a company plays a leading role in its management (especially in hard times), has resulted in more long-term-oriented corporate restructuring. Between the 1950s and the 1990s, similar results were produced in France and Korea by a government-dominated corporate system (through government ownership of banks and state-owned enterprises).

Another important, but neglected, set of institution of industrial restructuring is those institutions that facilitate the re-allocation of workers according to the new industrial needs. Industrial restructuring is often delayed - or even thwarted altogether - due to resistance from the workers, who understandably resist changes that involve job losses and/or significant re-configuration of their skills, which carries a lot of risk and resources. The decline of many British and American industries has owed a lot to such resistances. As a result, countries that have institutions that reduce workers' resistances to restructuring are better at industrial restructuring. In Japan, this was facilitated by the so-called 'lifetime employment' system, in which corporations implicitly guaranteed their core workers (roughly top $2 / 3$ of them in large corporations and top $1 / 3$ in smaller ones) employment and re-assigned them to new jobs (including to jobs in supplier companies, in case of large companies), if their existing jobs are eliminated. In Scandinavia, corporate restructuring was facilitated by the combination of the institution of a strong welfare state, which guaranteed decent living standards during unemployment, and the institutions of effective worker retraining and re-location programmes, which together made the workers very accepting of industrial restructuring.

\subsection{Institutions of macroeconomic management for industrialisation}

Studies of institutions have been mostly in microeconomics - such as the studies of property rights institutions and corporate governance institutions - and political economy - such as democracy and state bureaucracy. In contrast, macroeconomics has been almost been an "institution-free-zone", with the wage bargaining institutions in the developed countries being the only major exception. However, there are other several institutions playing a critical role in the macroeconomic management of the industrialisation process.

Successful industrialisation requires institutions of macroeconomic management that provide long-term-oriented finance at reasonable interest rates, an exchange rate that is not structurally over-valued, and economic stability (not just narrowly defined in terms of consumer prices but also in terms of output, employment, balance of payments, asset prices, and wages). The major institutioins that are required to provide such a macroeconomic environment include the following.

First, we need a central bank that is designed to provide: (i) economic stability in the broader sense (and not just low inflation) and not just focused on keeping consumer price inflation low; (ii) interest rates that are not overly high; (iii) currency values that are not 'over-valued' (especially important in natural-resource-rich countries with potentials for 'Dutch Disease'); and (iv) targeted and subsidised financing for projects of national significance (for further discussions, see Epstein, 2007).

Second, we need a set of budgetary institutions that include: (i) a broad-based tax system with minimum possibilities of tax evasion; (ii) a public expenditure system that provide automatic stabilisers (e.g., the welfare state, expenditure rules that limit 
pro-cyclical spending); and (iii) budgetary rules that allow active Keynesian fiscal policy (so, no rigid rules on public debt or budget deficit).

Third, we need institutions of financial regulation that: (i) reduce the procyclicality of the financial system; (ii) control asset price inflation (which is often ignored in the making of monetary policy by the central bank); and (iii) encourage long-term finance (see section 4.4 above).

Fourth, we need price- and wage-setting institutions that encourage macroeconomic stability, reduce social conflict, and encourage efficient industrial restructuring. The necessary institutions would include (i) a collective wage bargaining system that reduce competitive wage inflation or deflation across firms and sectors (e.g., centralised wage bargaining as in Scandinavia or strong normsetting by leading unions, as in Germany); (ii) a competition commission that acknowledges the need of collusive price-setting arrangements by leading firms during economic downturn or times of major industrial restructuring (e.g., Japan's state-sanctioned recession cartels) but strictly supervises them.

\section{Concluding Remarks}

While the role of institutions in economic development, and industrialisation in particular, was central among classical development economists in the 1940s-1960s, this idea remained largely ignored by the mainstream (Neoclassical) economists for several decades, to be rediscovered only at the end of the last century among development economists. By reviewing the history of economic analysis of institutions in economic development, the chapter has provided a long term perspective to engage critically with current debates on the role of institutions in economic development. In particular, we have disentangled the problems associated with widely adopted definitions of institutions as well as poor conceptualisation of their relationship with economic development.

The chapter has proposed to move beyond mainstream analyses of institutions and their relationships with economic development by focusing on the variety of forms and functions that institutions have taken historically, and even more critically on their collective nature. Building on Abramovitz's concept of social capability understood as "tenacious societal characteristics" embedded in productive organisations, as well as a variety of political, commercial, industrial and financial institutions, the chapter has emphasised the importance of developing productive capabilities, not just at the individual or the firm level but also at the sectoral and social level, in the process of economic development, and especially industrialisation.

This development requires long-term investments in specific human and physical assets, in private and public knowledge, and in industrial ecosystems. The range of institutions required to facilitate these investments are many and complex, which means that the recipe for institutional reform made by mainstream institutional discourse - a (Anglo-American) legal system that strongly protects private property rights and provides maximum freedom to 'do business' - is far too simplistic. The review of six different types of institutions for industrialisation has highlighted both the variety of types, forms and functions that they have taken historically among today's developed countries, as well as the need for coordination among different constituencies across the private and public spectrum.

Only when we understand the multiplicity and the complexity of the institutions necessary for industrialisation, on the one hand, and the variety of the institutional forms that we can adopt, on the other hand, will the developing countries be able to 
change their institutions in ways that are truly helpful for their economic development. Research engaging with the variety of types, forms and functions of institutions are critical in this respect as they allow policymakers to engage with the policy opportunities as well as the implementation challenges involved in governing complex processes of institutional building and change. 


\section{Bibliography}

Abramovitz, M. 1986. 'Catching Up, Forging Ahead, and Falling Behind', Journal of Economic History, 46: 385-406.

Abramovitz, M. 1995. The Elements of Social Capability. In Social Capability and Long-Term Economic Growth (B. H. Koo, \& D. H. Perkins, Trans., pp. 19-47). Basingstoke and London: Macmillan.

Acemoglu, D., Johnson, S. and Robinson, J. 2001. 'The Colonial Origins of Comparative Development: An Empirical Investigation', American Economic Review, 91(5).

Acemoglu, D., Johnson, S. and Robinson, J. 2005. 'Institutions as the Fundamental Cause of Long-Run Growth in P. Aghion \& S. Durlauf (eds.), Handbook of Economic Growth, North-Holland, Amsterdam.

Acemoglu, D. \& J. Robinson 2012. Why Nations Fail - The Origins of Power, Prosperity, and Poverty, Penguin Random House, London and New York.

Andreoni, A. 2014. Structural Learning: embedding discoveries and the dynamics of production, Structural Change and Economic Dynamics, 29,58-74.

Andreoni, A. 2015. 'On Manufacturing Development under Resources Constraints', in Baranzini, M., Rotondi, C. and Scazzieri, R. (eds.), Resources, Production and Structural Dynamics, Cambridge University Press, Cambridge.

Andreoni, A. 2016. Varieties of Industrial Policy: Models, Packages and Transformation Cycles, in Noman, A. and Stiglitz, J. (eds.), Efficiency, Finance and Varieties of Industrial Policy, New York, Columbia University Press, 245305.

Andreoni, A. 2018. The Architecture and Dynamics of Industrial Ecosystems: Diversification and Innovative Industrial Renewal in Emilia Romagna, Cambridge Journal of Economics, forthcoming.

Andreoni, A. and Chang, H-J. (2014) 'Agricultural policy and the role of intermediate institutions in production capabilities transformation: Fundacion Chile and Embrapa in action', to be presented at the DRUID Annual Conference, Copenhagen, Denmark.

Andreoni A. and Scazzieri, R. 2014. Triggers of Change: structural trajectories and production dynamics, Cambridge Journal of Economics, 38,6,1391-1408.

Andreoni, A. and Chang, H.-J. 2017. Bringing production and employment back into development, Cambridge Journal of Regions, Economy and Society, 10,173-187.

Andreoni, A., Frattini, F. and Prodi, G. 2017. Structural Cycles and Industrial Policy Alignment: The private-public nexus in the Emilian packaging valley, Cambridge Journal of Economics, 41,3,881-904.

Andreoni, A., Chang, H-J. and Estevez, 2018. New Global Rules, Policy Space and Quality of Growth in Africa' I. REFERENCE BOOK by NOMAN AND STIGLITZ forthcoming - to be completed in the editing process.

Aoki, M. 2001. Toward a Comparative Institutional Analysis, MIT Press, Cambridge Mass.

Aoki, M. and Hayami, Y. 2001. Eds. Communities and Markets in Economic Development, Oxford University Press, Oxford.

Aron, J. 2000. 'Growth and Institutions: A Review of the Evidence', The World Bank Research Observer, 15(1).

Chang, H-J. 2001. 'Intellectual Property Rights and Economic Development Historical Lessons and Emerging Issues', Journal of Human Development, 2(2). 
Chang, H-J. 2002. 'Breaking the Mould - An Institutionalist Political Economy Alternative to the Neo-Liberal Theory of the Market and the State', Cambridge Journal of Economics, vol. 26, no. 5.

Chang, H-J. (ed.) 2007a. Institutional Change and Economic Development, United Nations University Press, Tokyo, and Anthem Press, London.

Chang, H-J. 2007b. 'Understanding the Relationship between Institutions and Economic Development' in H-J. Chang (ed.), Institutional Change and Economic Development, United Nations University Press, Tokyo, and Anthem Press, London.

Chang, H-J. 2007c. Bad Samaritans, Random House, London, and Bloomsbury, New York.

Chang, H-J. 2010. 'Hamlet without the Prince of Denmark: How Development Has Disappeared from Today's 'Development” Discourse' in S. Khan \& J. Christiansen (eds.), Towards New Developmentalism: Market as Means rather than Master, Routledge, Abingdon.

Chang, H-J. 2011. Institutions and Economic Development: Theory, Policy, and History', Journal of Institutional Economics, 7(4).

Chang, H-J. 2018. 'The Rise and Fall (?) of ABP (Anything But Policy) Discourse in Development Economics' in A. Ghosh Dastidar, R. Malhotra \& V. Suneja (eds.), Economic Theory and Policy amidst Global Discontent - Essays in Honour of Deepak Nayyar, Routledge, Abingdon, 2018

Chang, H-J. and Evans, P. 2005. 'The Role of Institutions in Economic Change' in G. Dymski and S. Da Paula (eds), Reimagining Growth, London, Zed Press.

Chang, H-J. and Rowthorn, R. 1995. 'Role of the State in Economic Change:

Entrepreneurship and Conflict Management' (co-author: Bob Rowthorn) in H-J.

Chang \& B. Rowthorn (eds.), The Role of the State in Economic Change, Oxford University Press, Oxford

Cimoli, M., G. Dosi and J. Stiglitz. 2009. Eds. Industrial Policy and Development. The Political Economy of Capabilities Accumulation, Oxford University Press, Oxford.

Coase, R. H. 1937. 'The Nature of the Firm', Economica, 4(16): 386-405.

Epstein, J. 2007. 'Central Banks as Agents of Economic Development' in H-J. Chang (ed.), Institutional Change and Economic Development, United Nations University Press, Tokyo, and Anthem Press, London.

Georgescu-Roegen, N. (1976; 1st edition in 1965) 'Institutional Aspects of Peasant Economies: an Analytical View', in N. Georgescu-Roegen, Energy and Economic Myths - Institutional and Analytical Economic Essays, Pergamon Press, New York and Oxford.

Harriss, J., Hunter, J. and Lewis, C.M. (eds.) 1995. The New Institutional Economics and Third World Development, Routledge, London.

Hodgson, G. 2000. 'Structures and Institutions: Reflections on Institutionalism, Structuration Theory and Critical Realism', mimeo, The Business School, University of Hertfordshire.

Hodgson, G. 2006. 'What Are Institutions?', Journal of Economic Issues, 40(1):1-25. Hodgson, G. 2009. 'On the Institutional Foundation of Law: The Insufficiency of Custom and Private Ordering', Journal of Economic Issues, 43(1).

Hope, C. \& Chang, H-J. 2018. 'The Political Economy of Structural Transformation', mimeo., Centre of Development Studies, University of Cambridge. 
IEG (Independent Evaluation Group of the World Bank) 2010. The World Bank's Country Policy and Institutional Assessment - An Evaluation, World Bank, Washington, D.C..

Kapur, D. and Webber, R. 2000. 'Governance-related Conditionalities of the IFIs', G24 Discussion Paper Series, no. 6, Geneva, UNCTAD.

Keefer, P. 2011. 'Institutions really don't matter for development?: A response to Chang', Journal of Institutional Economics, 7(4).

Kitching, G. 1982. Development and Underdevelopment in Historical Perspective: Populism, Nationalism and Industrialisation, Methuen, London.

Kaufmann, D., A. Kraay, and P. Zoido-Lobaton 1999. 'Governance Matters', Policy Research Working Paper no. 2196, World Bank, Washington, DC.

Kuznets, S. 1966. Modern Economic Growth: Rate, Structure and Spread, Yale University Press, New Haven, CT.

La Porta, R., F. Lopez, de Salinas, A. Shleifer \& R. Vishny 1997. 'Legal Determinants of External Finance', Journal of Finance, 52(3).

La Porta, R., F. Lopez, de Salinas, \& A. Shleifer 2008. 'The economic consequences of legal origins', Journal of Economic Literature, 46(2).

Langlois, R. (ed.) 1986. Economics as a Process, Cambridge, Cambridge University Press.

Langlois, R. 1998. 'Capabilities and the Theory of the Firm', in Foss N. and B. Loasby (eds.) Economic Organization, Capabilities and Coordination, Routledge, London.

Lazonick, W. 2009. Sustainable prosperity in the new economy?, UPJOHN Institute. Lazonick, W. 2014. 'Profits without Prosperity', Harvard Business Review, Sept. Maddison, A. 1989. The World Economy in the 20th Century, OECD, Paris.

March, J. and Simon, H. 1958. Organizations, John Wiley and Sons Inc., New York.

Michaels, R. 2009. 'Comparative Law by Numbers? - Legal Origins Thesis, Doing Business Reports, and the Silence of Traditional Comparative Law', American Journal of Comparative Law, 57 (4): 765-795.

North, D. 1990. Institutions, Institutional Change and Economic Performance, Cambridge University Press, Cambridge.

North, D. 1994. 'Economic Performance through Tie', American Economic Review, 84 (3):359-67.

North, D. 1995. 'The New Institutional Economics and Third World Development' in Harriss, J., Hunter, J. and Lewis, C.M. (1995) eds., The New Institutional Economics and Third World Development, Routledge, London.

North, D. 2005. Understanding the Process of Economic Change, Princeton University Press, Princeton and Oxford.

Ostrom, E. 1990. Governing the Commons: The Evolution of Institutions for Collective Action, Cambridge University Press, Cambridge.

Penrose, E. T. 1959. The Theory of the Growth of the Firm, Oxford University Press, Oxford.

Simon, H. 1983. Reason in Human Affairs, Stanford University Press, Stanford.

Singh, A. 1971. Take-overs: Their Relevance to the Stock Market and the Theory of the Firm, Cambridge University Press, Cambridge.

Singh, A. 2003. 'Competition, Corporate Governance and Selection in Emerging Markets', Economic Journal, 113: F443-64.

Spraos, J. 1983. Inequalising Trade?, Clarendon Press, Oxford.

Stiglitz, J. 2007. Making Globalization Work, Allen Lane, London 
Tassey, G. 2005. 'Underinvestment in Public Good Technologies', Journal of Technology Transfer, 30: 89-113.

Van Noor, S. 2018. 'Checks and Balances, Private Property Rights and Economic Development: What the Data Really Tells Us', mimeo, Centre of Development Studies, University of Cambridge.

Veblen, T. B. 1899. The Theory of the Leisure Class: An Economic Study in the Evolution of Institutions, Macmillan, New York.

World Bank. 2002. World Development Report 2002, New York, Oxford University Press.

World Bank. 2017. World Development Report 2017, New York, Oxford University Press. 